\title{
FORAGING BEHAVIOUR OF SOME PAPILIONID BUTTERFLIES IN BHAWAL AND MADHUPUR SAL FORESTS OF BANGLADESH
}

\author{
Chowdhury, M. A. K. \\ Department of Zoology, Life and Earth Science Group, National University, Gazipur-1704, Bangladesh
}

\begin{abstract}
Foraging behaviour of nine papilionid butterflies have been studied from two moist deciduous sal forests viz. Bhawal and Madhupur from central part of Bangladesh. Papilionid butterflies were found to visit 156 flowering plant species belong to 39 plant families. Dependency of papilionid butterflies on flowering plants varied from family to family with high dependency on family Asteraceae $(15 \%)$ followed by Rubiaceae $(8 \%)$, Rutaceae (6\%), Verbenaceae (6\%), Apocynaceae (6\%) and Fabaceae (6\%). Although most of the plant species (72 species, $47.68 \%$ ) were visited by single butterfly species but some were also visited by multiple species of butterflies (e.g., Chromolaena odorata by 9 species, followed by Mikania cordata and Lantana camara by 8 and 7 species, respectively). Ninety eight percent (153 out of 156 species) of the nectar resources were dicotyledonous in origin but two percent plant species (three out of 156 species under three families) were monocotyledonous. Six floral attributes such as plants life forms, nature, perennation, origin, corolla shape and flower massing contributed butterflies significantly to visit plants for nectaring.
\end{abstract}

Key words: Papilionid butterfly; Foraging behaviour; Sal forests; Plant family; Floral attributes.

\section{INTRODUCTION}

Feeding is a significant activity and food may often be the most decisive factor affecting distribution, abundance and movements of animals (Kunte 2000). Among insect pollinators, butterflies are suitable model organisms to investigate foraging behaviour, because they can be easily monitored under natural circumstances (Lebeau et al. 2017).

Adult butterflies need nectar host plants as a main food source in the form of flower nectar (Shanmugapriya and Vanitharani 2015). Nectar is selected from available resources for optimal intake (Hantson and Baz 2013, Thomas and Schultz 2016). The foraging activity of butterflies play significant role in co-evolution between the butterfly species and the flowers of the nectar plants (Sultana et al. 2017) that benefits the plant species to achieve pollination and subsequent fruit set and enhance butterfly reproduction (Rani and Raju 2016). Thus establishes strong gene-flow mechanism in the forest ecosystem (Bashar 2018).

Over the entire period of their active life, butterflies engage in a spectrum of plant-feeding relationships which are often very complex involving coevolution and obligate mutualism (Gilbert 1975) and synchronization (Akand et al. 2015, Aich et al. 2016). Butterflies visit a wide range of flowers (Dosa 1999) and are considered as diverse pollinators on the vegetation of the ground surface layer, undergrowth layer, man height layer as well the canopy layer (Bashar et al. 2015, Bashar 2016). However, their choice of flowers is not random and do not feed indiscriminately from any flower they find (Tiple et al. 2006). They often exhibit distinct flower preferences that can differ between species (Tudor et al. 2004) and also are known to differ in the flowering species they visit (Corbet 2000, Tudor et al. 2004). Even when several species of flowers are simultaneously in blossoms, most flowervisiting insects utilize not all flowers but specific ones for energy resources (Dobson 1994).

Insect pollinators display a variety of flower-visiting behaviours that attract specific pollinators to promote intraspecific pollen transfer (Larsson 2005). Pollinators use plant cues (floral traits) to distinguish between morphologically identical plants to facilitate exploitation of nectar sources (Chittka and Raine 2006). Among the floral cues patterns of flowers and time of anthesis (Dosa 1999, Sourakov 2012); shape (Gunathilagaraj et al. 1998), size (Waser and Price 1983) and clustering (Corbet 2000) are 
very important. Pollinators perceive diverse floral signals and cues and modify their foraging behaviour in response, thereby affecting both their own foraging success and the plants' reproductive prospects.

Diversity of nectar host plants and abundance of butterflies have a direct relationship (Ferrer-Paris et al. 2013). The difference in the availability of butterflies in different habitats indicated the differences in plant diversity among the habitats (Akand et al. 2019). The herbaceous nectar plant species richness is very important for the support of adult butterfly species maintenance, and is most important for conservation of butterfly diversity in an area (Tiple et al. 2012, Khan 2015). Furthermore, an understanding of flower use and flower preferences is required to manage habitats for butterflies (Hardy et al. 2007).

Some research on butterfly has been done for nectar plant choices in some forests and gardens of Bangladesh (Bashar et al. 2006) including Bhawal and Madhupur Sal Forests (Akand et al. 2017, Alam et al. 2017, Kamrunnahar et al. 2018). And study on species specific foraging behaviour stands as most essential attempt in the field of butterfly conservation research. Determining the list of plant species used for nectaring, their foraging behaviour, as well as the spatio-temporal differences in their use is very important. Therefore, in the present study the correlation between papilionid butterflies and their nectar plant diversity has been investigated and tried to identify the floral resources within the Bhawal and Madhupur Sal Forests especially at the level of species and respective foraging behaviour of butterflies to utilize these resources. Present work studied flower visiting behaviour of nine papilionid butterflies and their floral resources to uncover relationships of butterflies with their feeding plants.

\section{MATERIAL AND METHODS}

Findings presented here are based on a field survey and investigation carried out on weekly survey basis in all months of the year as part of an ongoing grand experimentation programme for conservation of diversity of butterflies and wildlife as a whole in natural habitats of Bangladesh. Present study has been done at 10 selected study sites (five from each) of two deciduous moist sal forest of Bhawal and Madhupur twice in a month at each station. Bhawal Sal Forest is situated in Gazipur District, $40 \mathrm{Km}$ North of Dhaka City on both side of Dhaka-Mymensingh highway and its GPS location is $24^{\circ} 01^{\prime} \mathrm{N}, 90^{\circ} 20^{\prime} \mathrm{E}$. Madhupur Sal Forest is situated in the Madhupur Upazilla of Tangail District, $120 \mathrm{Km}$ North of Dhaka City. It is located between $23^{0} 50^{\prime}-24^{0} 50^{\prime} \mathrm{N}$ latitude and $89^{0} 54^{\prime}-90^{0} 50^{\prime} \mathrm{E}$ longitude. Present study was conducted in the core areas of both the forests (Fig. 1.).

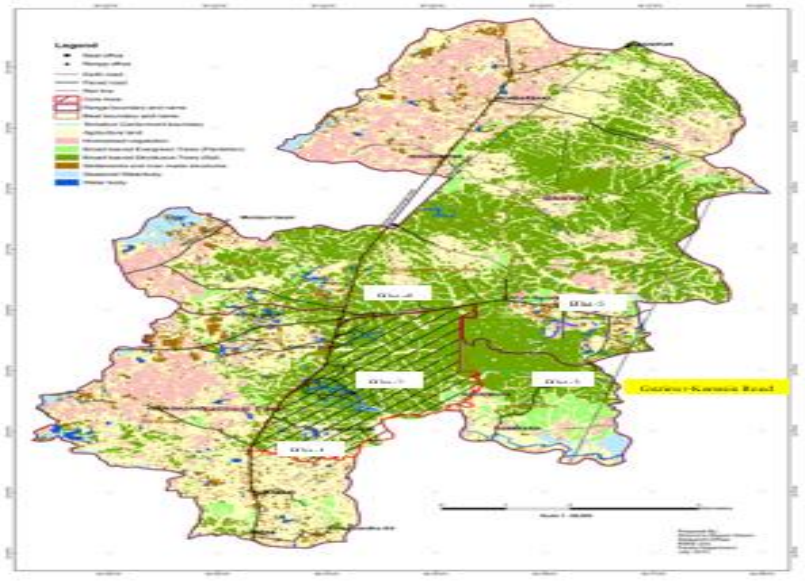

a

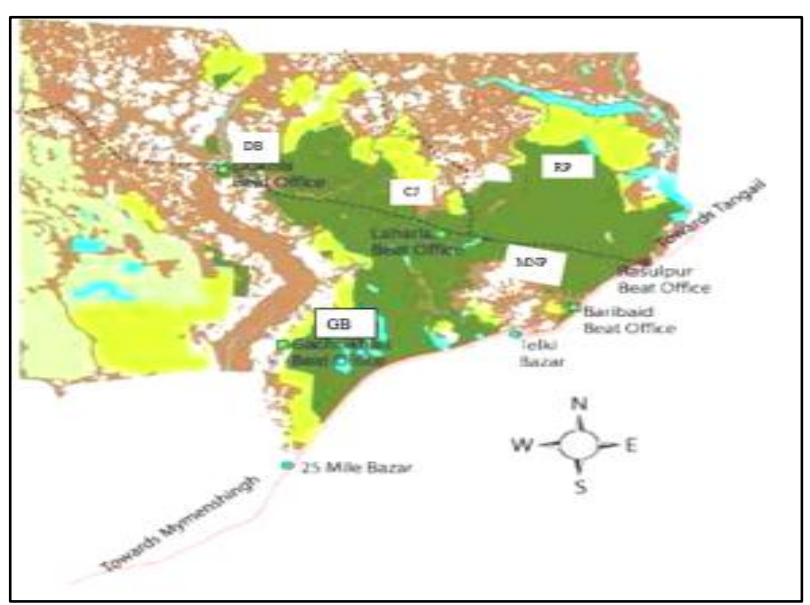

b

Fig. 1. Map of study areas: a. Bhawal Sal Forest, Gazipur; and b. Madhupur Sal Forest, Tangail. 
Sweep net method and visual observations were made to document papilionid butterflies visiting preferred flowers. Pollard walk method along a fixed transect of about 500m length with 5m on either side covered in an hour walking at a constant pace in each study site was utilized to document the butterflies and their activities on each sampling occasion. All butterflies were recorded with time and number of individuals seen between 7.30 and $18.00 \mathrm{hrs}$ and sometimes up to $19.00 \mathrm{hrs}$ according to Bangladesh Standard Time (BST) format when butterflies were actively foraging on flowers.

Butterflies were tracked while they foraged, maintaining a distance of at least $2 \mathrm{~m}$ to avoid disturbance. Flowers that fell $5 \mathrm{~m}$ on either side of transacts were considered to have been encountered by butterflies irrespective of their height and were recorded. Visits were scored only if it had been seen the butterflies probe the flower. Different behavioural activities regarding feeding of butterflies were studied using focal-animal sampling method described by Altmann (1974), Martin and Bateson (2007). In the present study, the focal animal was butterflies of family Papilionidae in which all occurrences of specified (inter) actions of an individual, or specified group of individuals, were recorded during each sampling period. Each individual was tracked and observed for 5 minutes for recording various feeding behaviours like foraging and nectaring.

Recording of specific observations were made upon each plant species visited by butterflies following Kato et al. (1990); phylogenetical features of nectar plant family (Weller et al. 1996). A data set of the nectar plants of all butterflies visited to flowers was prepared following (Chakraborty et al. 2017 and Ahmed et al. 2009), and also for more specific information followed Braby et al. (2006) in order to explain butterfly diet. All statistical analyses were performed using SPSS 24 and PAST online statistical packages following Kirkman (1996) and Wessa (2007).

\section{RESULTS AND DISCUSSION}

Recording of 1760 nectaring events for nine papilionid butterfly species on 156 species of flowering plants of 39 families have been made from Bhawal and Madhupur Sal Forests. Taxonomic comparisons were carried out to ascertain the size of the nectar feeding guild of papilionid butterflies at species level and presented in Table 1.

Table 1. Nectar plant features and their floral attributes associated with foraging activities of papilionid butterflies in the experimental stations of Bhawal and Madhupur Sal Forests of Bangladesh.

\begin{tabular}{|c|c|c|c|c|c|c|c|c|c|c|c|c|c|c|c|c|c|}
\hline \multirow{2}{*}{$\begin{array}{l}\text { Plants } \\
\text { life } \\
\text { forms }\end{array}$} & \multicolumn{3}{|c|}{ Nature } & \multicolumn{3}{|c|}{ Origin } & \multicolumn{2}{|c|}{ Perennation } & \multicolumn{2}{|c|}{ Corolla shape } & \multicolumn{3}{|c|}{ Flower massing } & \multicolumn{3}{|c|}{ Biotope } & \multirow{2}{*}{$\begin{array}{l}\text { Total } \\
(\%)\end{array}$} \\
\hline & $\begin{array}{c}\mathrm{C} \\
(\%)\end{array}$ & $\begin{array}{c}\mathrm{W} \\
(\%)\end{array}$ & $\begin{array}{c}\mathrm{M} \\
(\%)\end{array}$ & $\begin{array}{c}\mathrm{N} \\
(\%)\end{array}$ & $\begin{array}{l}\mathrm{Na} \\
(\%)\end{array}$ & $\begin{array}{c}\text { I } \\
(\%)\end{array}$ & $\begin{array}{c}\mathrm{A} \\
(\%)\end{array}$ & $\begin{array}{c}\mathrm{P} \\
(\%)\end{array}$ & $\begin{array}{c}\mathrm{Nt} \\
(\%)\end{array}$ & $\begin{array}{c}\mathrm{T} \\
(\%)\end{array}$ & $\begin{array}{c}\mathrm{D} \\
(\%)\end{array}$ & $\begin{array}{c}\mathrm{M} \\
(\%)\end{array}$ & $\begin{array}{c}\mathrm{S} \\
(\%)\end{array}$ & $\begin{array}{l}\text { BSF } \\
(\%)\end{array}$ & $\begin{array}{c}\mathrm{MSF} \\
(\%)\end{array}$ & $\begin{array}{c}\text { Both } \\
(\%)\end{array}$ & \\
\hline Climbers & $\begin{array}{c}7 \\
(4)\end{array}$ & $\begin{array}{c}7 \\
(4)\end{array}$ & $\begin{array}{c}4 \\
(3)\end{array}$ & $\begin{array}{c}13 \\
(8)\end{array}$ & $\begin{array}{c}3 \\
(2)\end{array}$ & $\begin{array}{c}2 \\
(1)\end{array}$ & $\begin{array}{c}7 \\
(4)\end{array}$ & $\begin{array}{l}11 \\
\text { (7) }\end{array}$ & $\begin{array}{c}5 \\
(3)\end{array}$ & $\begin{array}{c}13 \\
(8)\end{array}$ & $\begin{array}{l}10 \\
(6)\end{array}$ & $\begin{array}{c}1 \\
(1)\end{array}$ & $\begin{array}{c}7 \\
(4)\end{array}$ & $\begin{array}{c}3 \\
(2)\end{array}$ & $\begin{array}{c}0 \\
(0)\end{array}$ & $\begin{array}{c}15 \\
(10)\end{array}$ & $\begin{array}{c}18 \\
(12)\end{array}$ \\
\hline Herbs & $\begin{array}{c}28 \\
(18)\end{array}$ & $\begin{array}{c}28 \\
(18)\end{array}$ & $\begin{array}{c}7 \\
(4)\end{array}$ & $\begin{array}{c}29 \\
(19)\end{array}$ & $\begin{array}{c}13 \\
(8)\end{array}$ & $\begin{array}{c}21 \\
(14)\end{array}$ & $\begin{array}{c}50 \\
(32)\end{array}$ & $\begin{array}{c}13 \\
(8)\end{array}$ & $\begin{array}{c}26 \\
(17)\end{array}$ & $\begin{array}{c}37 \\
(24)\end{array}$ & $\begin{array}{c}31 \\
(20)\end{array}$ & $\begin{array}{l}14 \\
(9)\end{array}$ & $\begin{array}{c}18 \\
(12)\end{array}$ & $\begin{array}{c}6 \\
(4)\end{array}$ & $\begin{array}{c}2 \\
(1)\end{array}$ & $\begin{array}{c}55 \\
(35)\end{array}$ & $\begin{array}{c}63 \\
(40)\end{array}$ \\
\hline Shrubs & $\begin{array}{c}23 \\
(15) \\
\end{array}$ & $\begin{array}{c}15 \\
(10) \\
\end{array}$ & $\begin{array}{c}15 \\
(10) \\
\end{array}$ & $\begin{array}{c}38 \\
(24) \\
\end{array}$ & $\begin{array}{c}5 \\
(3) \\
\end{array}$ & $\begin{array}{l}10 \\
\text { (6) }\end{array}$ & $\begin{array}{c}3 \\
(2) \\
\end{array}$ & $\begin{array}{c}50 \\
(32)\end{array}$ & $\begin{array}{c}20 \\
(13)\end{array}$ & $\begin{array}{c}33 \\
(21) \\
\end{array}$ & $\begin{array}{c}29 \\
(19) \\
\end{array}$ & $\begin{array}{c}9 \\
(6) \\
\end{array}$ & $\begin{array}{c}15 \\
(10) \\
\end{array}$ & $\begin{array}{c}8 \\
(5) \\
\end{array}$ & $\begin{array}{c}2 \\
(1) \\
\end{array}$ & $\begin{array}{c}43 \\
(28) \\
\end{array}$ & $\begin{array}{c}53 \\
(34) \\
\end{array}$ \\
\hline Trees & $\begin{array}{c}8 \\
(5) \\
\end{array}$ & $\begin{array}{c}6 \\
(4) \\
\end{array}$ & $\begin{array}{c}8 \\
(5)\end{array}$ & $\begin{array}{c}18 \\
\text { (12) }\end{array}$ & $\begin{array}{c}0 \\
(0)\end{array}$ & $\begin{array}{c}4 \\
\text { (3) }\end{array}$ & $\begin{array}{c}0 \\
(0)\end{array}$ & $\begin{array}{c}22 \\
(14)\end{array}$ & $\begin{array}{c}6 \\
(4) \\
\end{array}$ & $\begin{array}{c}16 \\
(10)\end{array}$ & $\begin{array}{c}14 \\
(9)\end{array}$ & $\begin{array}{c}5 \\
(3) \\
\end{array}$ & $\begin{array}{c}3 \\
(2) \\
\end{array}$ & $\begin{array}{c}2 \\
(1)\end{array}$ & $\begin{array}{c}3 \\
(2) \\
\end{array}$ & $\begin{array}{c}17 \\
(11)\end{array}$ & $\begin{array}{c}22 \\
(14)\end{array}$ \\
\hline Total & $\begin{array}{c}66 \\
(42)\end{array}$ & $\begin{array}{c}56 \\
(36)\end{array}$ & $\begin{array}{c}34 \\
(22)\end{array}$ & $\begin{array}{c}98 \\
(63)\end{array}$ & $\begin{array}{c}21 \\
\text { (13) }\end{array}$ & $\begin{array}{c}37 \\
(24)\end{array}$ & $\begin{array}{c}60 \\
(38)\end{array}$ & $\begin{array}{c}96 \\
(62)\end{array}$ & $\begin{array}{c}57 \\
(37)\end{array}$ & $\begin{array}{c}99 \\
(63)\end{array}$ & $\begin{array}{c}84 \\
(54)\end{array}$ & $\begin{array}{c}29 \\
(19)\end{array}$ & $\begin{array}{c}43 \\
(28)\end{array}$ & $\begin{array}{c}19 \\
\text { (12) }\end{array}$ & $\begin{array}{c}7 \\
(4)\end{array}$ & $\begin{array}{l}130 \\
(83)\end{array}$ & $\begin{array}{c}156 \\
(100)\end{array}$ \\
\hline
\end{tabular}

$\mathrm{C}=$ Cultivated, $\mathrm{W}=$ Wild, $\mathrm{M}=$ Mixed (Wild \& cultivated), $\mathrm{N}=$ Native, Na=Naturalized, I=Introduced, $\mathrm{A}=\mathrm{Annuals}, \mathrm{P}=\mathrm{Perennials,}$ $\mathrm{Nt}=$ Nontubular, $\mathrm{T}=$ Tubular, $\mathrm{D}=$ Dense, $\mathrm{M}=$ Moderate, $\mathrm{S}=$ Sparse, BSF=Bhawal Sal Forest, MSF=Madhupur Sal Forest, Both=BSF \& MSF.

Papilionidae butterflies feeding more on herbs (63 species, 40\%) and shrubs (53 species, 34\%) than on trees (22 species, 14\%) and climbers (18 species, 12\%). They also preferred feeding on flowers of cultivated plants (42\%) than to wild plants (36\%) and mixed (Wild and cultivated) plants (22\%), and 
also on native plants (63\%) than to naturalized $(13 \%)$ or introduced plants $(24 \%)$, and on perennials (62\%) than annuals (38\%). Papilionidae also showed clear preference to feed on plants with dense massing $(54 \%)$ flowers than to moderate $(19 \%)$ or sparse massing $(27 \%)$ flowers, and for tubular flowers $(63 \%)$ than to nontubular ones (37\%) (Fig. 2).

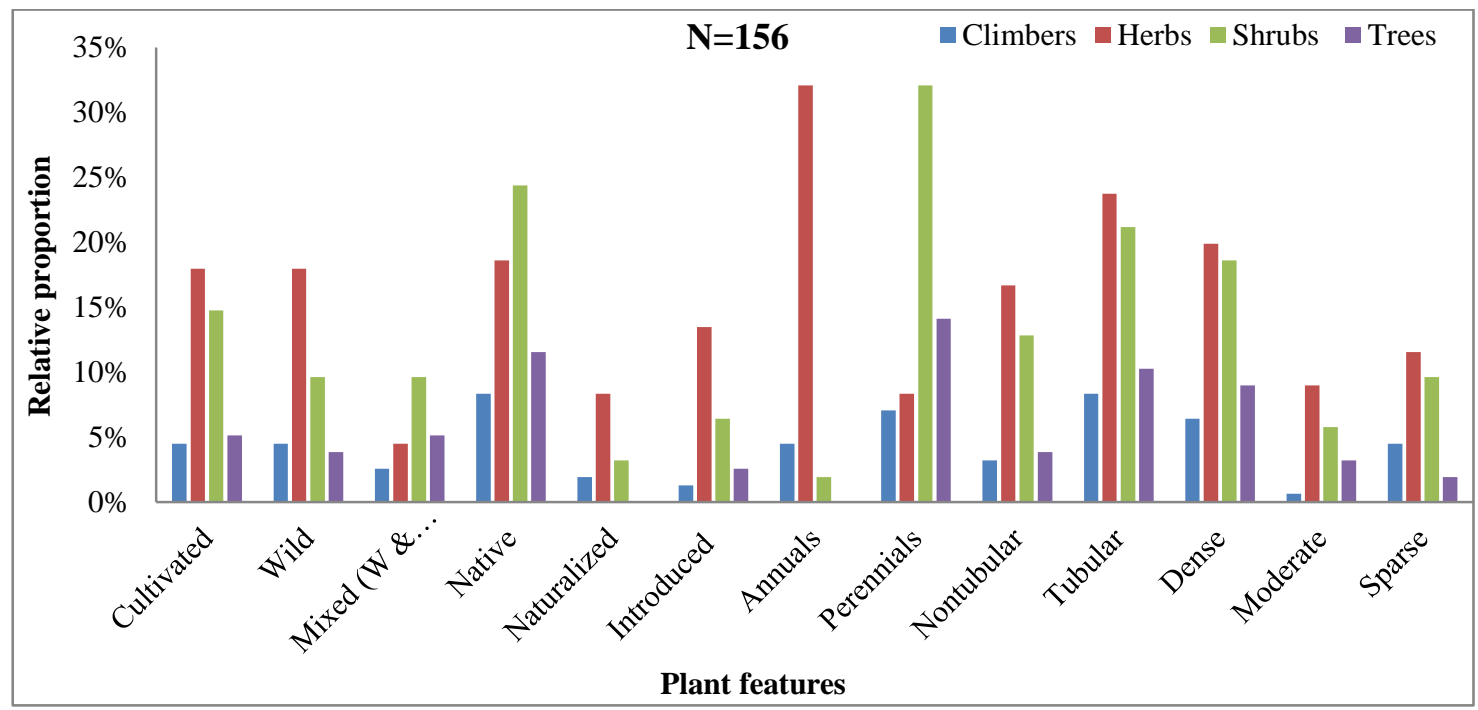

Fig. 2. Relative proportion of plant features that attracted papilionid butterflies to visit for nectaring.

Both the study areas have almost similar floristic composition with some differences for e.g. family Myrsinaceae, Myrtaceae, Plumbaginaceae and Vitaceae, these were not recorded from Madhupur Sal Forest (Fig. 3.).

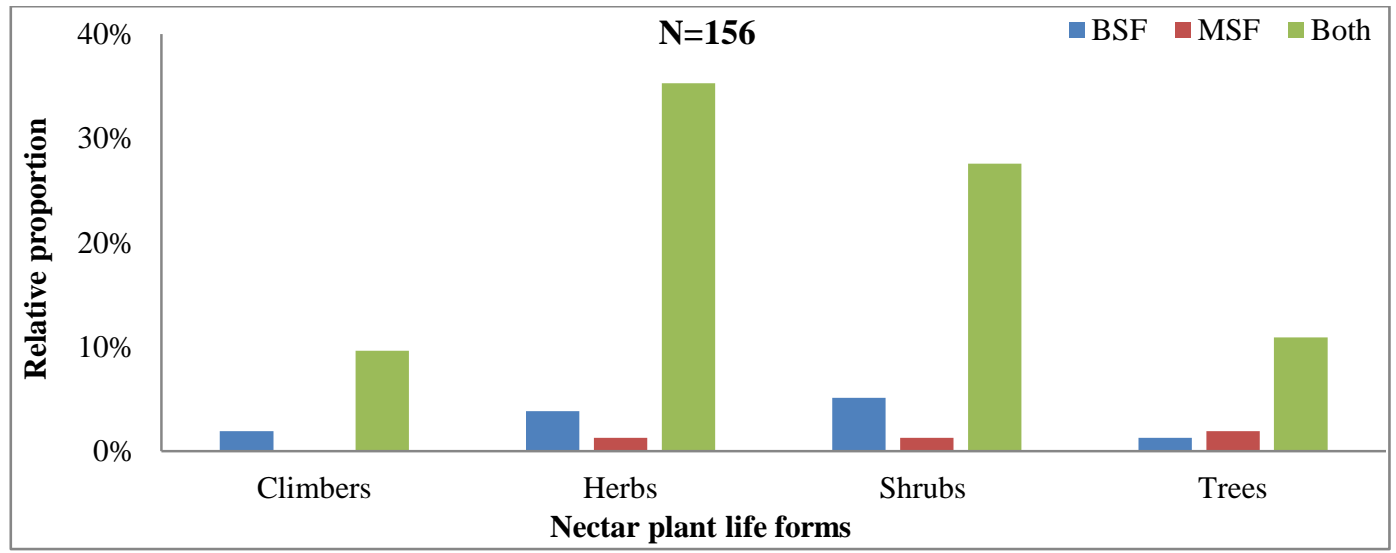

Fig. 3. Relative composition of nectaring species of papilionid butterflies in the experimental stations.

Most butterflies have specific habitat and food requirements (Feltwell 1986) to maximize net energy gain during foraging (Hainsworth and Hamill 1993). Moreover, polyphagous natures shown by certain butterfly species help adopt to live at diversified habitats and hence become common (Hameed 2007).

Visits of flowering plants species varied among butterfly species. For example, Papilio polytes collected nectar from as many as 104 plant species followed by $P$. demoleus fed on nectar of 94 species. On the other hand, Chilasa paradoxa was found to visit only flowers of Chromolaena odorata (Table 2). Frequency of nectaring events also varied among the species for example, Papilio demoleus was 
recorded to visit various flowering species for 666 times during the study period whereas Chilasa paradoxa was recorded to visit nectaring plants only for two times.

Table 2. List of papilionid butterfly with features of nectar plants, number of nectar plant species visited and number of nectaring events.

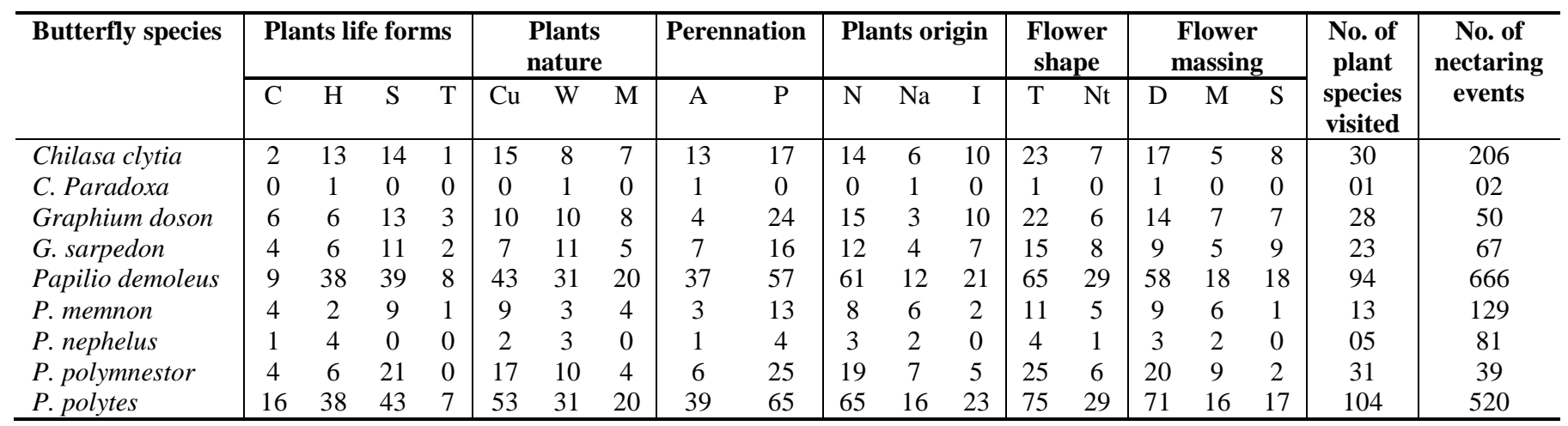

$\mathrm{C}=$ Climbers, $\mathrm{H}=$ Herbs, $\mathrm{S}=$ Shrubs, $\mathrm{T}=$ Trees, $\mathrm{Cu}=$ Cultivated, $\mathrm{W}=$ Wild, $\mathrm{M}=$ Mixed (Wild \& cultivated), $\mathrm{N}=$ Native, $\mathrm{Na}=$ Naturalized, I=Introduced, $\mathrm{A}=$ Annuals, $\mathrm{P}=$ Perennials, $\mathrm{Nt}=$ Nontubular, $\mathrm{T}=$ Tubular, $\mathrm{D}=$ Dense, $\mathrm{M}=$ Moderate, $\mathrm{S}=$ Sparse.

Butterflies and many species of flowering plants are interdependent (Kunte 1997) and butterfly diversity clearly indicated the floral diversity of an ecosystem. The maintenance and management of herbaceous plant species richness and diversity in a butterfly habitat, is important for ensuring the nectar resources for adult butterflies and very important for conservation of butterfly diversity (Kitahara et al. 2008).

Papilionidae showed bias for feeding on herbs and shrubs than for trees and climbers. They also preferred feeding on flowers of cultivated plants than the wild and mixed (wild \& cultivated) plants and also showed bias for native plants than naturalized or introduced plants and for perennials than annuals. Papilionidae also showed bias for feeding on plants with dense massing flowers than on moderate or sparse massing flowers and for tubular flowers than nontubular ones. However, among the papilionid Papilio demoleus, $P$. polytes, $P$. nephelus, Chilasa clytia and $C$. paradoxa showed some more attraction to flowers of annuals and herbs and nontubular flowers as do Graphium doson, G. sarpedon, Papilio memnon and P. polymnestor to flowers of perennials, shrubs and trees, and tubular ones (Fig. 3).

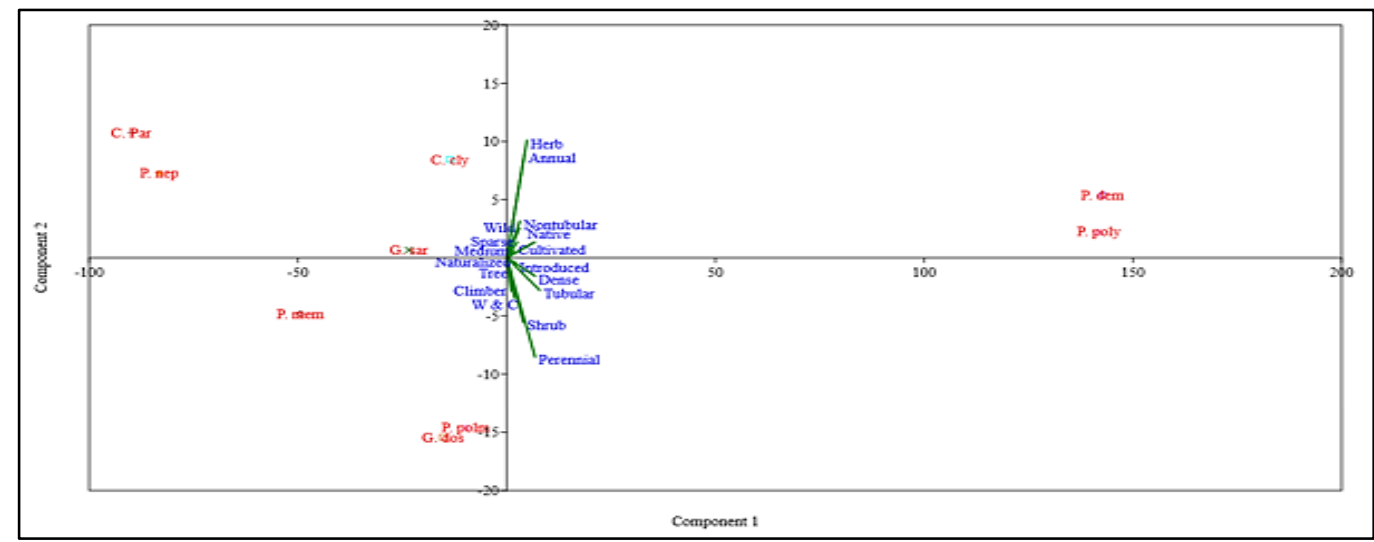

Fig. 3. Principal components analysis (PCA) of different floral attributes of flowering plants (156 species) visited by examined papilionid butterfly species. Component 1 , explain $97.17 \%$ and component $2,1.23 \%$ variance. Number of flowering plants used and number of nectaring events are standardized on number of observations on transects for each butterfly species and are entered as supplementary for analysis. [C. cly $=$ Chilasa clytia, C. par $=$ Chilasa paradoxa, G. dos = Graphium doson, G. sar = Graphium sarpedon, $\mathrm{P}$. dem=Papilio demoleus, $\mathrm{P} . \mathrm{mem}=$ Papilio memnon, P. nep = Papilio nephelus, . polym =Papilio polymnestor and P. poly=Papilio polytes $]$. 
Butterflies forage on flowers of ground vegetation, herbs, shrubs as well as trees and often their flight period synchronized with the plant phenological stages (Akand et al. 2016). They behave like opportunistic foragers (Courtney and Shapiro 1986) during nectar gathering, but their choice of flowers is not random, often they possess species specific flower preferences. Learned behaviour is a feature of flower constancy (Goulson et al. 1997a, b). Nectar resources for adults are likely important limiting factors (Gilbert and Singer 1975) and may shape community patterns (Gilbert 1984).

Ninety eight percent (153 out of 156 species) of the nectar sources were dicotyledonous in origin. Only three species one from each of family Asparagaceae, Colchicaceae and Iridaceae were monocotyledonous comprising only $2 \%$ of the total number of plant species utilized (Fig. 4.).

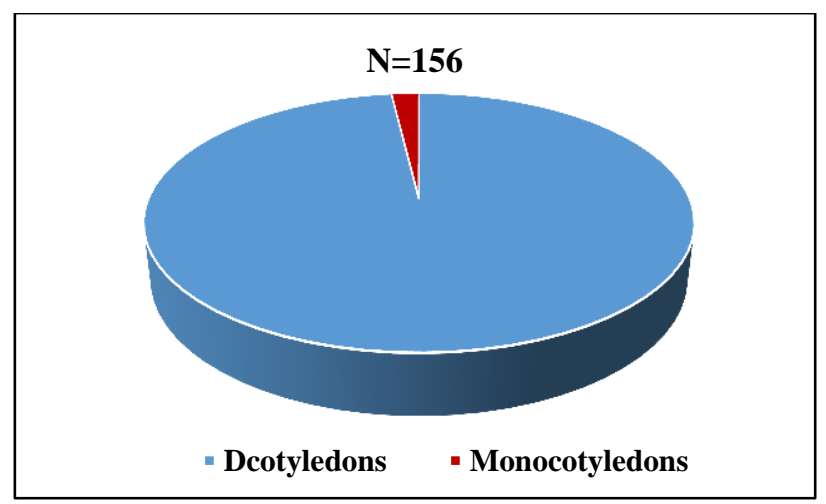

Fig. 4. Types of plants utilized by papilionid butterflies.

Butterfly depends more on dicotyledons than on monocotyledons (Ghosh and Saha 2016). Adults are dependent on nectar and pollen as their primary nutritional resource (Nimbalkar et al. 2011). Differences of nectar plant use between sexes and generations (as food and mode of feeding vary with life stages) of butterflies are reported (Bakowski and Doku-Marfo 2009). Since butterflies are in close relationship with vegetation, they indicate the floral diversity of a habitat. The nature of vegetation is an important factor that determines the survival of herbivores in a particular habitat (Sharma and Sharma 2013, Chandekar et al. 2014).

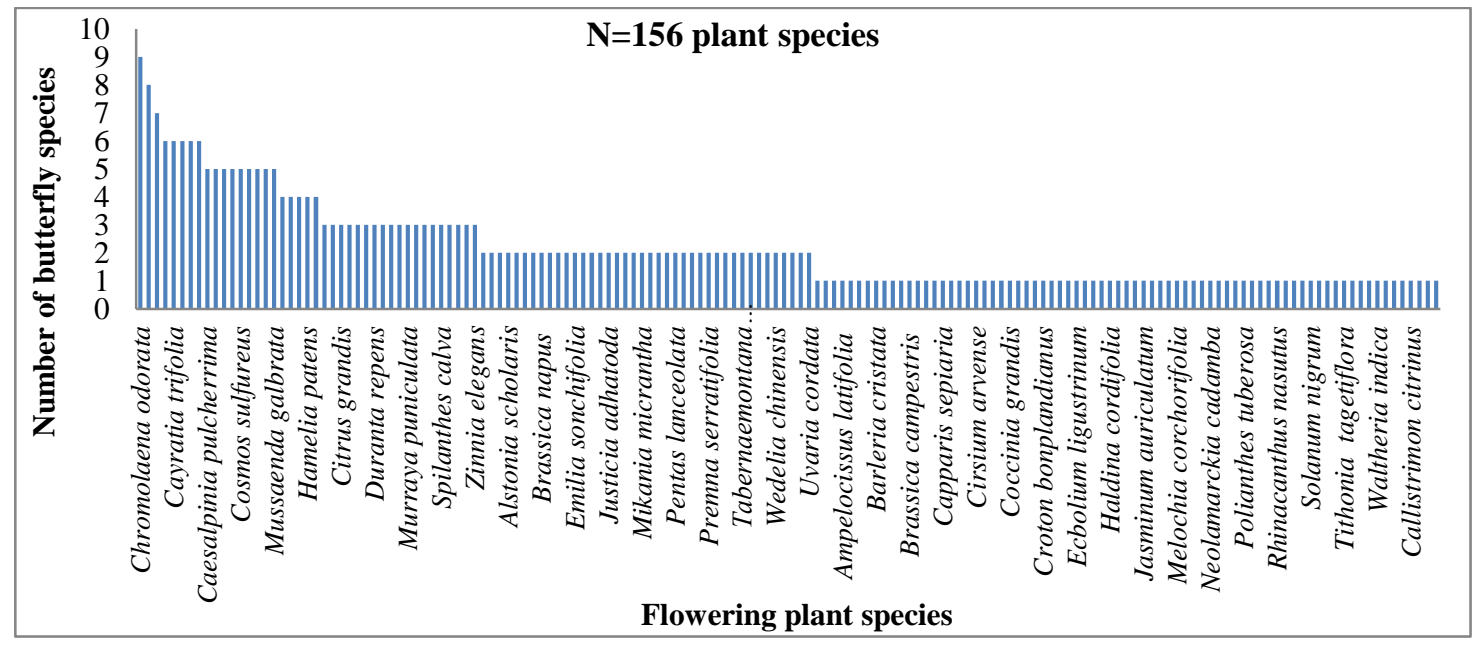

Fig. 5. Number of papilionid butterfly species per plant species visiting for nectar.

Flowers of most of the plant species (72 species, 47.68\%) were visited by single butterfly species. But some flowering plant species were also visited by multiple species of butterflies (e.g., Chromolaena 
odorata by 9 species, followed by Mikania cordata and Lantana camara by 8 and 7 species, respectively) (Fig. 5).

Dependency of papilionid butterflies on flowering plants varied from family to family with high dependency on species of flowering plants of the family Asteraceae (15\%), Rubiaceae (8\%), Rutaceae $(6 \%)$, Verbenaceae $(6 \%)$, Apocynaceae $(6 \%)$ and Fabaceae $(6 \%)$. However, dependency was only one percent for 20 families (Table 3).

Table 3. List of nectar plant family and relative dependency of species of papilionid butterflies on them.

\begin{tabular}{|c|c|c|c|c|c|c|c|c|c|c|}
\hline \multirow[t]{2}{*}{ Plants family } & \multicolumn{9}{|c|}{ No. of plant species visited by each butterfly species } & \multirow{2}{*}{$\begin{array}{c}\text { Relative } \\
\text { Dependency } \\
(\%)\end{array}$} \\
\hline & $\begin{array}{c}\text { Chilasa } \\
\text { clytia }\end{array}$ & $\begin{array}{c}\text { Chilasa } \\
\text { paradoxa }\end{array}$ & $\begin{array}{c}\text { Graphium } \\
\text { doson }\end{array}$ & $\begin{array}{c}\text { Graphium } \\
\text { sarpedon }\end{array}$ & $\begin{array}{c}\text { Papilio } \\
\text { demoleus }\end{array}$ & $\begin{array}{c}\text { Papilio } \\
\text { memnon }\end{array}$ & $\begin{array}{c}\text { Papilio } \\
\text { nephelus }\end{array}$ & $\begin{array}{c}\text { Papilio } \\
\text { polymnestor }\end{array}$ & $\begin{array}{l}\text { Papilio } \\
\text { polytes }\end{array}$ & \\
\hline Acanthaceae & 2 & 0 & 1 & 1 & 4 & 0 & 0 & 0 & 6 & 5 \\
\hline Amaranthaceae & 2 & 0 & 0 & 0 & 2 & 0 & 0 & 0 & 3 & 2 \\
\hline Annonaceae & 0 & 0 & 2 & 0 & 1 & 1 & 0 & 0 & 1 & 2 \\
\hline Apocynaceae & 2 & 0 & 1 & 1 & 8 & 1 & 0 & 1 & 7 & 6 \\
\hline Asclepiadaceae & 0 & 0 & 0 & 1 & 1 & 0 & 0 & 0 & 0 & 1 \\
\hline Asparagaceae & 0 & 0 & 0 & 0 & 0 & 0 & 0 & 0 & 1 & 1 \\
\hline Asteraceae & 7 & 1 & 6 & 5 & 16 & 2 & 2 & 4 & 21 & 15 \\
\hline Boraginaceae & 0 & 0 & 0 & 1 & 1 & 0 & 0 & 0 & 1 & 2 \\
\hline Brassicaceae & 0 & 0 & 0 & 0 & 3 & 1 & 0 & 0 & 2 & 3 \\
\hline Caesalpiniaceae & 1 & 0 & 0 & 0 & 1 & 1 & 0 & 1 & 2 & 1 \\
\hline Capparaceae & 0 & 0 & 0 & 1 & 2 & 0 & 0 & 0 & 1 & 3 \\
\hline Colchicaceae & 0 & 0 & 0 & 0 & 0 & 1 & 0 & 0 & 0 & 1 \\
\hline Combretaceae & 0 & 0 & 0 & 0 & 1 & 0 & 0 & 0 & 1 & 1 \\
\hline Crassulaceae & 0 & 0 & 0 & 0 & 1 & 0 & 0 & 0 & 1 & 1 \\
\hline Cucurbitaceae & 0 & 0 & 0 & 0 & 0 & 0 & 0 & 0 & 6 & 4 \\
\hline Euphorbiaceae & 2 & 0 & 0 & 0 & 1 & 0 & 0 & 0 & 2 & 2 \\
\hline Fabaceae & 0 & 0 & 1 & 0 & 4 & 0 & 0 & 0 & 5 & 6 \\
\hline Iridaceae & 0 & 0 & 0 & 0 & 1 & 0 & 0 & 0 & 0 & 1 \\
\hline Lamiaceae & 2 & 0 & 1 & 0 & 3 & 0 & 0 & 0 & 3 & 3 \\
\hline Linaceae & 0 & 0 & 0 & 0 & 1 & 0 & 0 & 0 & 0 & 1 \\
\hline Malvaceae & 1 & 0 & 2 & 0 & 2 & 2 & 1 & 4 & 4 & 4 \\
\hline Melastomataceae & 0 & 0 & 0 & 1 & 0 & 0 & 1 & 0 & 0 & 1 \\
\hline Mimosaceae & 0 & 0 & 0 & 1 & 0 & 0 & 0 & 0 & 0 & 1 \\
\hline Moringaceae & 0 & 0 & 0 & 0 & 1 & 0 & 0 & 0 & 0 & 1 \\
\hline Myrsinaceae & 0 & 0 & 0 & 0 & 1 & 0 & 0 & 0 & 0 & 1 \\
\hline Myrtaceae & 0 & 0 & 0 & 0 & 1 & 0 & 0 & 0 & 0 & 1 \\
\hline Nyctaginaceae & 0 & 0 & 2 & 2 & 2 & 1 & 0 & 1 & 3 & 2 \\
\hline Oleaceae & 0 & 0 & 0 & 0 & 3 & 0 & 0 & 0 & 2 & 3 \\
\hline Plantaginaceae & 0 & 0 & 0 & 0 & 1 & 0 & 0 & 0 & 0 & 1 \\
\hline Plumbaginaceae & 0 & 0 & 0 & 0 & 1 & 0 & 0 & 0 & 0 & 1 \\
\hline Polygonaceae & 0 & 0 & 1 & 0 & 1 & 0 & 0 & 1 & 1 & 1 \\
\hline Rhamnaceae & 0 & 0 & 0 & 0 & 0 & 0 & 0 & 1 & 1 & 1 \\
\hline Rosaceae & 0 & 0 & 0 & 0 & 1 & 0 & 0 & 0 & 0 & 1 \\
\hline Rubiaceae & 3 & 0 & 5 & 3 & 9 & 1 & 1 & 5 & 9 & 8 \\
\hline Rutaceae & 1 & 0 & 1 & 0 & 8 & 1 & 0 & 5 & 11 & 6 \\
\hline Solanaceae & 0 & 0 & 0 & 1 & 3 & 0 & 0 & 1 & 1 & 3 \\
\hline Sterculiaceae & 0 & 0 & 0 & 1 & 0 & 0 & 0 & 1 & 0 & 1 \\
\hline Verbenaceae & 6 & 0 & 4 & 3 & 8 & 3 & 0 & 5 & 8 & 6 \\
\hline Vitaceae & 1 & 0 & 1 & 1 & 1 & 1 & 0 & 1 & 1 & 1 \\
\hline Total & 30 & 1 & 28 & 23 & 94 & 16 & 5 & 31 & 104 & 100 \\
\hline
\end{tabular}

Adult feeding has long been shown to be of vital importance for somatic maintenance and reproduction, and so population persistence, in butterflies (Tudor et al. 2004). There is a positive relationship between the total number of visitor species found in a community at a given time and the floral abundance of all plant species while nectar volume, nectar sugar composition or energy content of pollen were unrelated with the number of visitor species (Potts et al. 2003). Gutierrez and Mendez 
(1995) suggested that the abundance of butterflies is more related to the availability of food plants than any other factors. Plants have importance in increasing the butterfly diversity and their abundance in an area (Prajapati et al. 2000).

Table 4. Correlations (Pearson Correlations) between plant life forms and floral attributes.

\begin{tabular}{lcccccc}
\hline Variables & Life forms & Nature & Perennation & $\begin{array}{c}\text { Plants } \\
\text { origin }\end{array}$ & $\begin{array}{c}\text { Flower } \\
\text { shape }\end{array}$ & $\begin{array}{c}\text { Flower } \\
\text { massing }\end{array}$ \\
\hline Life forms & 1 & $0.248^{* *}$ & $0.308^{* * *}$ & $0.132^{* * *}$ & -0.010 & $0.388^{* * *}$ \\
Nature & $0.248^{* *}$ & 1 & $0.113^{* *}$ & $0.370^{* * *}$ & -0.019 & $0.179^{* * *}$ \\
Perennation & $0.308^{* *}$ & $0.113^{* *}$ & 1 & $0.109^{* *}$ & $0.095^{* *}$ & $0.092^{* *}$ \\
Plants origin & $0.132^{* *}$ & $0.370^{* *}$ & $0.109^{* *}$ & 1 & 0.014 & $0.175^{* *}$ \\
Corolla shape & -0.010 & -0.019 & $0.095^{* *}$ & 0.014 & 1 & $0.109^{* *}$ \\
Flower massing & $0.388^{* *}$ & $0.179^{* *}$ & $0.092^{* *}$ & $0.175^{* *}$ & $0.109^{* *}$ & 1 \\
\hline Correlation is significant at the 0.01 level (2-tailed), *Correlation is significant at the 0.05 level (2-tailed).
\end{tabular}

All of the six variables were found to contribute significantly to the number of visits of butterfly. All other floral attributes were linked up with plant life forms and contributed significantly to the visitation of flowers. However, plants life form is strongly correlated with plants nature (Spearman $\mathrm{r}=0.248$ ), perennation $(r=0.308)$, plants origin $(r=0.132)$ and flower massing $(r=0.388)$ but weakly negatively correlated with flower shape (-0.010) (Table 4).

Table 5. Correlations between plant life forms and floral attributes.

\begin{tabular}{|c|c|c|c|c|c|c|c|}
\hline Variables & $\mathbf{N}$ & F value & $\overline{\mathbf{R}^{2}}$ & $\begin{array}{l}\text { t-Test } \\
\text { value }\end{array}$ & $\begin{array}{c}\text { Mean } \\
\text { difference }\end{array}$ & $\chi^{2}$-value & Sig. \\
\hline Plant families & 39 & 64.50 & 9581.98 & 75.98 & 21.42 & 5164.25 & 0.000 \\
\hline Plants life forms & & 6.44 & 4.67 & 180.75 & 2.60 & 191.39 & 0.000 \\
\hline Climbers & 18 & 15.17 & 0.69 & & & & 0.000 \\
\hline Herbs & 63 & 129.50 & 0.94 & & & & 0.000 \\
\hline Shrubs & 53 & 91.40 & 0.92 & & & & 0.000 \\
\hline Trees & 22 & 34.16 & 0.82 & & & & 0.000 \\
\hline Plants Nature & & 15.64 & 9.26 & 104.06 & 1.68 & 38.54 & 0.000 \\
\hline Cultivated & 66 & 97.52 & 0.93 & & & & 0.000 \\
\hline Wild & 56 & 217.10 & 0.96 & & & & 0.000 \\
\hline Mixed (Wild \& cultivated) & 34 & 52.82 & 0.88 & & & & 0.000 \\
\hline Perennation & & 52.81 & 11.06 & 217.87 & 1.77 & 36.45 & 0.000 \\
\hline Annual & 60 & 141.80 & 0.95 & & & & 0.000 \\
\hline Perennial & 96 & 106.50 & 0.93 & & & & 0.000 \\
\hline Plants origin & & 53.83 & 20.51 & 167.51 & 1.86 & 103.02 & 0.000 \\
\hline Native & 98 & 159.50 & 0.95 & & & & 0.000 \\
\hline Naturalized & 21 & 83.85 & 0.92 & & & & 0.000 \\
\hline Introduced & 37 & 17.59 & 0.71 & & & & 0.000 \\
\hline Flower shape & & 12.98 & 2.54 & 816.27 & 1.98 & 60.73 & 0.000 \\
\hline Tubular & 99 & 139.30 & 0.95 & & & & 0.000 \\
\hline Non-tubular & 57 & 108.80 & 0.99 & & & & 0.000 \\
\hline Flower massing & & 31.76 & 18.01 & 102.73 & 1.75 & 113.23 & 0.000 \\
\hline Dense & 84 & 25.30 & 0.97 & & & & 0.000 \\
\hline Moderate & 29 & 28.40 & 0.80 & & & & 0.000 \\
\hline Sparse & 43 & 30.20 & 0.62 & & & & 0.000 \\
\hline
\end{tabular}

Test of significance at $95 \%$ confidence limit, Values are significant at $\mathrm{P}=0.01$ level

To determine the main influences across butterfly species visits to nectar sources, number of visits of butterfly species have been directly tested for a broad range of six floral attributes such as plant life 
forms (herbs and shrubs versus trees and climbers), nature of plants (wild versus cultivated), perennation (annual versus perennial), plants origin (native versus naturalized/introduced), flower shape (tubular versus non-tubular) and flower massing (dense versus sparse/moderate) at $\mathrm{P}=0.001$ level. There were distinctive and highly significant associations between butterfly species and floral attributes have been revealed and presented in Table 5 .

There was a significant relationship between butterfly species and nectar plant families $(\mathrm{F}=64.50$, $\mathrm{R}^{2}=9581.98, \mathrm{P}=0.000<0.001, \mathrm{~N}=39$ plant families). But there was also a significant difference in flowering plants choices among butterfly species ( $\mathrm{t}=75.97$ with mean differences of 21.42, $\mathrm{P}=0.000<0.001)$. However, a distinctive and highly significant plant family-butterfly species associations have also been revealed $\left(\chi^{2}=5164.25, \mathrm{P}=0.000<0.001\right)$, although many of the papilionid butterfly species used same nectar resources.

Floral attributes contributed significantly to the test statistic. Test statistics: plants life forms (climbers, herbs, shrubs and trees), $\chi^{2}=191.39$; plants nature (wild, cultivated, mixed (wild and cultivated) $\chi^{2}=38.54$; perennation (annual and perennial), $\chi^{2}=36.45$; origin of plants (native, naturalized and introduced) $\chi^{2}=103.02$; flower shape (tubular and non-tubular), $\chi^{2}=60.73$; flower massing (sparse, moderate and dense) $\chi^{2}=113.23$ at $\mathrm{P}=0.000<0.001$ with $95 \%$ confidence limit.

Competition for nectar resources among butterflies clearly occurs (Porter et al. 1992). The assemblage of attributes that influences flower choice also influences other aspects of butterfly biology such as flight costs and rate of energy intake (Corbet 2000). This means that pollinators have to make economic choices about what type of flowers they visit to increase benefits (energy intake) compared to energy consumption, Amaya-Marquez (2009). Floral characteristics have been reported to be important for visitation by butterflies (Raju et al. 2003). The flowers of most of the plant species are believed to be adapted to attract restricted groups of pollinators (Bhuyan et al. 1999). So plants exhibit a tremendous diversity of floral traits that are often highly differentiated among closely related species. Thus, a distinctive association occurred among butterflies and plants for a range of attributes, on the plant side involving flower shape, corolla depth, life form and flower abundance, and on the butterfly side, involving proboscis length. These were maintained at higher taxonomic (butterfly family) level (Tiple et al. 2009).

The nectar resource utilization by adult butterflies is significantly biased to herbaceous plants, especially to perennials. A significant positive correlation in the number of species was detected between herbaceous and perennial plants. In arable field margins of Britain, the importance of perennial nectar sources rather than annual ones was pointed out for butterfly conservation and butterflies visited perennials more frequently than annuals in relation to their relative abundance (Dover 1996) as do bumblebees (Fussell and Corbet 1992a, b). Flowers visited by swallowtail butterflies also showed high variability in plant nature and flower masses (Hirota et al. 2012). Visual signals such as flower shape, and size can play an important role in flower detection and choice (Waser and Price 1983). Flower shape is often considered a key character that limits the types of visitors that can pollinate flowers. Butterflies were more abundant on tubular flowers than on open flowers (McCall and Primack 1992). Faegri and Van der Pijl (1979) also have the same notion that tubular flowers are pollinated more by butterflies, than open flowers.

Butterfly species and their dependency on locally available flora are well established at various habitats (Tiple et al. 2006). Native butterflies are associated with the prevailed local flora (Palot and Radhakrishnan 2004) and their distribution is directly linked with the local floral diversity (Kunte 1997). Invasive alien plant species have been shown to significantly affect plant-pollinator interactions. Evolutionary experience in using food resources of the alien vs. the native species might translate to lower decision rates to visit the alien plant (Buchholz and Kowarik 2019). When plant species are 
introduced into new communities, their interactions with herbivores vary; exotic plants may be avoided by native herbivores; or the exotic plants may have negative, positive or neutral effects on the native herbivores that consume them (Verhoeven et al. 2009).

\section{ACKNOWLEDGEMENTS}

Present article is the part of a grand research programme "Butterflies of Bangladesh and their conservation". The author acknowledges the Ministry of Education, Government of the People's Republic of Bangladesh for their financial support to the research programme. The author is grateful to Dr. M A Bashar, Professor, Department of Zoology, University of Dhaka, for his support and guidance as well as for allowing him in doing this research in the Environmental Biology and Biodiversity Laboratory (EBBL), Department of Zoology, University of Dhaka. He is thanked profusely by the author for his constructive recommendations and valuable comments in writing the manuscript. He additionally acknowledges the Forestry Division of the Ministry of Environment, Forest and Climate Change, Government of the People's Republic of Bangladesh for their assistance in conducting the research in the forests of Bangladesh.

\section{REFERENCES}

Ahmed, J. U., M. A. Hassan, Z. N. T. Begum and M. Khondker. 2009. Encyclopedia of flora and fauna of Bangladesh (Vol. 6-12). Asiatic Society of Bangladesh, Nimtali, Dhaka., pp. 1-3451.

Aich, U., S. Chowdhury, S. Akand, S. Rahman, K. Chowdhury, Z. Sultan and M. A. Bashar. 2016. Synchronization of coincidences between the life stages of Pachliopta aristolochiae and the phenological stages of its host plant Aristolochia indica. J. Biodivers. conserv. bioresour. manag. 2(2): 61-68.

Akand, S., M. A. Bashar and H. R. Khan. 2019. Status of lycaenid butterflies in some selected forests of Bangladesh. J. biodivers. conserv. bioresour. manag. 5(2): 19-32.

Akand, S., M. A. Bashar, H. R. Khan and S. Rahman. 2016. Abundance and some behavioural aspects of lycaenid butterflies in the Butterfly Research Park at the Bhawal National Park, Gazipur. $J$. biodivers. conserv. bioresour. manag. 2(2): 39-46.

Akand, S., M. A. Bashar, S. Rahman and H. R. Khan. 2017. Morphometric variation in the species of two subfamilies of lycaenid butterflies (Lepidoptera: Lycaenidae) of Bangladesh. J. biodivers. conserv. bioresour. manag. 3(1): 9-15.

Akand, S., S. Rahman, K. Chowdhury, M. M. Alam, G. Moula, H. R. Khan and M. A. Bashar. 2015. Behavioural activities of lycaenid butterflies and their significance with the related plants. $J$. biodivers. conserv. bioresour. manag. 1(2): 57-66.

Alam, S., M. A. Bashar, U. Aich, S. Akand and S. Rahman. 2017. Colonization and strategic stratification of butterfly Pachliopta aristolochiae (Lepidoptera: Papilionidae) and its relationship with the host plant Aristolochia indica (Piperales: Aristolochiaceae). J. biodivers. conserv. bioresour. manag. 3(1): 45-54.

Altmann, J. 1974. Observational study of behavior: sampling methods. Behaviour. 49: 227-267.

Amaya-Marquez, M. 2009. Floral constancy in bees: a revision of theories and a comparison with other pollinators. Rev. Colomb. Entomol. 35: 206-216.

Bakowski, M. and E. Doku-Marfo. 2009. A rapid biodiversity assessment of the Ajenjua Bepo and Mamang River Forest Reserves. Conserv. Int. 30: 33-33. 
Bashar, M. A. 2016. Vision on biodiversity: example of ecosystem services in Bangladesh. J. biodivers. conserv. bioresour. manag. 2(1): 1-6.

Bashar, M. A. 2018. Vision on biodiversity: ecotourism and biodiversity conservation in Bangladesh. $J$. biodivers. conserv. bioresour. manag. 4(1): 1-10.

Bashar, M. A., H. R. Khan, S. Rahman, Eftesum, K. M. Chowdhury, M. Alam and G. Moula. 2015. Wildlife conservation through butterfly colonization. J. biodivers. conserv. bioresour. manag. 1(1): 71-82.

Bashar, M. A., M. A. Mamun, A. F. M. Aslam and A. K. Chowdhury. 2006. Biodiversity maintenance and conservation of butterfly-plant association in some forests of Bangladesh. Bangladesh J. Zool. 34(1): 55-67.

Bhuyan, M., D. Kataki, M. Deka and P. R. Bhattacharyya. 1999. Nectar host plant selection and floral probing by the Indian butterfly Danaus genuita (Nymphalidae). J. Res. Lepidop. 38: 79-84.

Braby, M., R. Vila and N. E. Pierce. 2006. Molecular phylogeny and systematics of the Pieridae (Lepidoptera: Papilionoidea) higher classification and biogeography. Zool. J. Linn. Soc. 147(2): 239-275.

Buchholz, S. and I. Kowarik. 2019. Urbanization modulates plant-pollinator interactions in invasive vs. native plant species. Scientific Report. 9: 6375-6383.

Chakraborty, T. D., P. Chakrabarty and A. Chaudhury. 2017. An approach for butterfly conservation through setting up a garden in an urban area, Kolkata, India. World Scientific News. 61(2): 69-85.

Chandekar, S. K., R. K. Nimbalkar and A. A. Kuvalekar. 2014. The Seasonal Patterns in the Abundance of Butterflies, their biotopes and nectar food plants from Maval Tahsil, Pune District, Maharashtra, India. Int. J. Plant, Animal, Environ. Sci. 4(1): 50-64.

Chittka, L. and N. E. Raine. 2006. Recognition of flowers by pollinators. Curr. Opin. PlantBiol. 9:428-435.

Corbet, S. A. 2000. Butterfly nectaring flowers: butterfly morphology and flower form. Entomol. Exper. Appl. 96: 289-298.

Courtney, S. P. and A. M. Shapiro. 1986. The ecology and behavior of the high Andean butterfly Hypsochilawa genknechti (Lepidoptera: Pieridae). Stud. Neotrop. Fauna Environ. 21: 169-187.

Dobson, H. E. M. 1994. Floral volatiles in insect biology. In: E. A. Bernays (ed.). Insect-plant interactions. Vol V. CRC Press, Boca Raton FL., pp. 47-81.

Dosa, G. 1999. Flower visitation patterns of butterflies and burnet moths in the Aggtelek-Karst (Hungary). Nota Lepid. 22(1): 58-66.

Dover, J. W. 1996. Factors affecting the distribution of satyrid butterflies on arable farmland. J. Appl. Ecol. 33: 723-734.

Faegri, K. and L. Van Der Pijl. 1979. The principles of pollination ecology. Pergamon Press, Oxford, UK. 244 pp.

Feltwell, J. 1986. The natural history of butterflies. Christopher Helm Publishers Ltd, Provident House, Bureel Row, Beckenham Kent BR3 1AT, England. 133 pp.

Ferrer-Paris, J. R., A. Sanchez-Mercado, A. L. Viloria and J. Donaldson. 2013. Congruence and diversity of butterfly-host plant associations at higher taxonomic levels. PLoS One. 8(5): 1-15. 
Fussell, M. and S. A. Corbet. 1992a. Flower usage by bumble-bees: a basis for forage plant management. J. Appl. Ecol. 29: 451-465.

Fussell, M. and S. A. Corbet. 1992b. Forage for bumble bees and honey bees in farmland: a case study. J. Apicultur. Res. 30: 87-97.

Ghosh, S. and S. Saha. 2016. Seasonal diversity of butterflies with reference to habitat heterogeneity, larval host plants and nectar plants at Taki, North 24 Parganas, West Bengal, India. World Scientific News. 50: 197-238.

Gilbert, L. E. 1975. Ecological consequences of a coevolved mutualism between butterflies and plants. In: L. E. Gilbert and R. H. Raven (eds.). Coevolution of animals and plants. Univ. Texas Press, Austin., pp. 210-240.

Gilbert, L. E. 1984. The biology of butterfly communities. In: R. I. Vane-Wright and P. R. Ackery (eds.). The Biology of Butterflies. Academic Press, London, UK., pp. 41-54.

Gilbert, L. E. and M. C. Singer. 1975. Butterfly ecology. Ann. Rev. Ecol. Syst. 6: 365-397.

Goulson, D., J. C. Stout and S. A. Hawson. 1997b. Can flower constancy in nectaring butterflies be explained by Darwin's interference hypothesis? Oecologia. 112: 225-231.

Goulson, D., J. Ollerton and C. Sluman. 1997a. Foraging strategies in the small skipper butterfly, Thymelicus flavus: when to switch? Anim. Behav. 53: 1009-1016.

Gunathilagaraj, K., T. N. A. Perumal, K. Jayaram and M. G. Kumar. 1998. Field Guide: Some South Indian Butterflies, Project Life scape. Niligiri Wildlife and Environmental Association, Nilgiris, Bangalore, India. $274 \mathrm{pp}$.

Gutierrez, D. and R. Mendez.1995. Phenology of Butterflies in a mountain area in Northern Iberian Peninsula. Ecography. 18: 209-219.

Hainsworth, F. R. and T. Hamill. 1993. Foraging rules for nectar: food choices by painted ladies. Anim. Nat. 142(5): 857-867.

Hameed, S. V. A. 2007. Study of the ecology and diversity of butterflies (Class: Insecta: Order: Lepidoptera) in the Farook College Campus and adjacent areas, Kozhikode, Kerala. Minor research Project submitted to UGC. pp. 4-65.

Hantson, S. and A. Baz. 2013. Seasonal change in nectar preference for a mediterranean butterfly community. J. Lepidopterists' Soc. 67: 134-142.

Hardy, P. B., T. H. Sparks, N. J. B. Isaac and R. L. H. Dennis. 2007. Specialism for larval and adult consumer resources among British butterflies: implications for conservation. Biol. Conserv. 138: 440-452.

Hirota, S., K. Nitta, Y. Kim, A. Kato, N. Kawakubo, A. A. Yasumoto, T. Yahara and A. Akiko. 2012. Relative role of flower color and scent on pollinator attraction: Experimental tests using F1 and F2 hybrids of Daylily and Nightlily. PLoS One. 7(6): 1-10.

Kamrunnahar, S. Akand, S. Rahman, H. R. Khan and M. A. Bashar. 2018. Basking behaviour in some nymphalid butterflies of Bangladesh. J. biodivers. conserv. bioresour. manag. 4(1): 63-72.

Kato, M., K. T. Inoue and T. Itino. 1990. Insect-flower relationship in the primary beech forest of Ashu, Kyoto: An overview of the flowering phenology and seasonal pattern of insect visits. Contr. Biol. Lab. Kyoto Univ. 27: 309-375. 
Khan, A. H. 2015. Nectar Plant Resource Visits by Butterflies on a Nandanvan Tah. Sironcha, Dist. Gadchiroli, (M.S). Int. J. Res. Biosci. Agri. Technol. 1(1): 203-215.

Kirkman, T. W. 1996. Statistics to Use. http://www.physics.csbsju.edu/stats

Kitahara, M., M. Yumoto and T. Kobayashi. 2008. Relationship of butterfly diversity with nectar plant species richness in and around the Aokigahara primary woodland of Mount Fuji, central Japan. Biodivers. Conserv. 17: 2713-2734.

Kunte, K. 1997. Seasonal pattern in butterfly abundance and species diversity in four tropical habitats in northern Western Ghats. J. Biosci. 22(5): 593-603.

Kunte, K. 2000. Butterflies of Peninsular India. Universities Press, Hyderabad and Indian Academy of Sciences, Bengaluru, India. 270 pp.

Larsson, M. 2005. Higher pollinator effectiveness by specialist than generalist flower-visitors of unspecialized Knautia arvensis (Dipsacaceae). Oecologia. 146: 394-403.

Lebeau, J., R. A. Wesselingh and H. Van Dyck. 2017. Flower use of the butterfly Maniola jurtina in nectar-rich and nectar-poor grasslands: a nectar generalist with a strong preference? Insect Conserv. Divers. 10(3): 258-270.

Martin, P. and P. Bateson. 2007. Measuring Behaviour. An Introductory Guide. 3rd ed. Cambridge University Press, UK. 186 pp.

McCall, C. and R. B. Primack. 1992. Influence of flower characteristics, weather, time of day, and season on insect visitation rates in three plant communities. Am. J. Bot. 79(4): 434-442.

Nimbalkar, R. K., S. K. Chandekar and S. P. Khunte. 2011. Butterfly diversity in relation to nectar food plants from Bhor Tahsil, Pune District, Maharashtra, India. J. Threatened Taxa. 3(3): 1601-1609.

Palot, J. M. and C. Radhakrishnan. 2004. Butterflies in the Kerala part of Western Ghats. Pro. Nat. Sem. Cum-Workshop on butterfly diversity of Western Ghats, Kerala, India., pp. 20-33.

Porter, K., C. A. Steel and J. A. Thomas. 1992. The ecology of butterflies in Britain: Butterflies and communities. Oxford Univ. Press, New York, USA., pp. 139-177.

Potts, S. G., B. Vulliamy, A. Dafni, G. Ne'eman and P. Willmer. 2003. Linking bees and flowers: how do floral communities structure pollinator communities? Ecology. 84(10): 2628-2642.

Prajapati, B., U. Shrestha and A. S. Tamrakar. 2000. Diversity of Butterfly in Daman area of Makawanpur District, Central Nepal. Nepal J. Sci. Technol. 2: 71-76.

Raju, A. J. S., S. P. Rao and V. Ezradanam. 2003. Some ecological notes on the butterflies of Visakhapatnam, Andhra Pradesh. Zoos' Print J. 18(6): 1126-1128.

Rani, B. U. and A. J. S. Raju. 2016. A study on butterfly-flower interactions. J. Palynol. 52: 111-131.

Shanmugapriya, C. and J. Vanitharani. 2015. Ecosystem services of lepidoptera to the floral diversity of Mandapam Group of Islands. Scitech J. 2: 34-40.

Sharma, M. and N. Sharma. 2013. Nectar resource use by Butterflies in Gir-Wildlife Sanctuary, Sasan. Gujarat. Biol. Forum. J. 5(2): 56-63.

Sourakov, A., A. Duehl and A. Sourakov. 2012. Foraging behavior of the blue morpho and other tropical butterflies: The chemical and electrophysiological basis of olfactory preferences and the role of color. Psyche. 2012(8): 1-10. 
Sultana, S., S. Rahman, S. Akand, M. F. Hoque, M. S. Miah and M. A. Bashar. 2017. Butterfly probosces and their functional relations with the nectar plants in some selected forests. J. biodivers. conserv. bioresour. manag. 3(1): 93-101.

Thomas, R. C. and C. B. Schultz. 2016. Resource selection in an endangered butterfly: females select native nectar species. J. Wildl. Manage. 80: 171-180.

Tiple, A. D., A. M. Khurad and K. Kunte. 2009. Population dynamics and seasonal polyphenism of Chilades pandava butterfly (Lycaenidae) in Central India. Curr. Sci. 97(12): 1774-1779.

Tiple, A. D., V. D. Waykar and A. M. Khurad. 2012. Nectar plant resource visits by butterflies on a Futala Farm, Nagpur City (Central India). J. Sci. Inform. 3(1): 136-143.

Tiple, A. D., V. P. Deshmukh and R. L. H. Dennis. 2006. Factors influencing nectar plant resource visits by butterflies on a university campus: implications for conservation. Nota lepid. 28: 213-224.

Tudor, O., R. L. Dennis, J. N. Greatorex-Davies and T. H. Sparks. 2004. Flower preferences of woodland butterflies in the UK: nectaring specialists are species of conservation concern. Biol. Conserv. 119(3): 397-403.

Verhoeven, K. J. F., A. Biere, J. A. Harvey and W. H. Van Der Putten. 2009. Plant invaders and their novel natural enemies: who is naïve? Ecol Lett. 12: 107-117.

Waser, N. M. and M. V. Price. 1983. Pollinator behaviour and natural selection for flower colour in Delphinium nelsonii. Nature. 302: 422-424.

Weller, S. J., D. P. Pashley and J. A. Martin. 1996. Reassessment of butterfly family relationships using independent genes and morphology. Ann. Entomol. Soc. Am. 89(2): 184-192.

Wessa, P. 2007. Free Statistics Software, Office for Research Development and Education, version 1-121. https://www.wessa.net 